\title{
Chapter 20 \\ Business Investment and the Nigerian Investible Capital Haemorrhage in Financial Crises
}

\author{
Kehinde Adekunle Adetiloye \\ Covenant University, Nigeria
}

\begin{abstract}
The global financial crises that happened between 2007 and 2010 had deleterious effects on countries across the world including Nigeria with regard to their respective levels of globalisation. This was evidenced with sudden outflows of capital emanating from the capital market that impacted negatively on the banking system. The chapter has adopted a number of variables among which are investment and net portfolio investments and external reserves. The main technique used is the regression (both single and two-stage) the results of which indicate that the investment was not negatively impacted by the portfolio investment but had significantly negative effect on the external reserve and the saving of the country. The chapter recommends a better control of the capital out flows and improvement in the business environment to reduce the capital haemorrhage faced by the Nigerian economy.
\end{abstract}

\section{INTRODUCTION}

Capital is scarce commodity that responds to two basic stimuli: the return and the risk quotients. Holders and owners of capital weigh options available through simple and complicated processes of appraisals before committing this scarce resource wherever they choose. While financial theory has been resplendent on risk and returns issues and while private capital is more susceptible to financial market reactions, public capital is insufficient and less frequently or freely available to influence the market. The flows of capital between a country and the rest of the world are determined by domestic attractions and external repellents: the pull and the push factors. The domestic attractions to (long-term) investment of capital are inherent in the economic environment. The impacts of foreign capital on the domestic investment of the country can also be determined from the environment. While economists over the years have concentrated on foreign capital inflows, their concern about the domestic capital outflows have been treated with more of political motives than

DOI: $10.4018 / 978-1-4666-8274-0 . c h 020$ 
economic. Questions of colonialism and the like have been raised to support the reasons why capital often flow out of developing countries more often than it should to developed and mature financial markets (Ndukumana \& Boyce, 2003).

Capital outflows or flight out of any economy indicates the unsuitability of the economic environment to host and engage such capital domestically. This has been dealt with by many studies among which are Kindleberger (1987), Ajayi (1992) Collier, Hoefler \& Pattilo (2001). The causes of capital flight or continuous outflows are more than many studies have covered. Prominent among these are the portfolio choices theorem, exchange rate misalignment, and globalisation of finance as it concerns Nigeria (Adetiloye 2011), war and other disruptive events, coups and so many others. Issues such as financial globalisation have been raised if it significantly causes or increases capital outflows in developing countries. The dialectics of capital flight or flows are important when the economy involved is developing and in dire need of capital for development purposes. Adetiloye (2012) attempts a division between capital flows and flight on one hand and legal capital flight and an illegal one on the other. The matter at issue is the leakage of development fund or capital that can be productively and profitably engaged domestically for the development of the economy.

Financial theory postulates that risks determine the level of investment capital that can be engaged in any economy while it also establishes the threshold of the return possible. The fact that risks within the business environment can determine the flow of resources into a domestic economy is not in doubt. Throughout the world the flows of capital between low income and high income have followed an alternate boom and bust cycles (Lane \& Milessi-Ferretti, 2010) is well known. While capital flows within the developed markets is of little significance, attention has been focused more on the flows of capital between emerging economies of the world and the developed finan- cial markets. This is presumably on the basis of the fact that flows are more significant within this sector. A good case is Nigeria where many studies have been done on flight capital and yet more capital flight is still manifesting. It is either the policymakers are not concerned, intransigent or they lacked powers to make some changes. The belief of the study about this situation is that there is a laissez-faire attitude on the part of the Nigerian policymakers who appear and act helpless in the face of serious problems that can erode the base of the economy. Thus the economy has become an economy that thrives on continuous exploitation of resources, the net of which feeds other economies.

\section{OBJECTIVE OF THE CHAPTER}

The objective of this paper is to discuss financing investment within the business environment in the Nigerian economy and the impact of disruptive financial flows on investment in the economy. Specifically the chapter looks at the impact of hot flows as represented by the portfolio investment on the external reserves which represent the resources available externally to fund investment in the economy. The paper is divided into six major sections. Following after the introduction is the literature review on the business and investment environment and risks to business. Methodology adopted to explain the issues followed is followed by results and discussions. Section five is on the Nigerian crises and implication for confidence. The final section is on recommendations and conclusions

\section{LITERATURE REVIEW}

\section{Sources of Business Capital}

Theoretically, all sources of funds for business endeavours have come from principally two main sources: debt and equity, especially the micro and 
small sector have enjoyed other sources apart from this two. Notable among the other options being family or relations and friends who assist the entrepreneur to fund of desired business that is easily affordable. The other types of funds flowing to the real sector (traditionally seen as agriculture, manufacturing, mining and quarrying and real estate and construction) have come mainly from the savings of investors and through capital accumulation of different sources. The medium size industries have various government sources to support their investment activities with many of the funds at concessionary rates of interest or guaranteed by the government. Moses and Adebisi (2013) explore the assistance that could come from business angels existing in various forms to the small firms given their experience in business funding. Thus, funding small and micro businesses which have been touted to be the engine room of real and industrial progress has been stunted.

Greater challenges exist for the medium sector which unarguably would be of much help as the mainstay of employment and industrial progress for the Nigerian economy. Funding this sector has been problematic as banks are unwilling to assist the sector for a plethora of reasons, though this is not the only problem to investment in the real sectors in Nigeria. Financing sources include Development Finance Institutions, Commercial Banks(SMIEIS, direct lending, etc.), microfinance institutions, the capital market and private equity (Ovia, 2008). The development finance institutions in this sector have failed to assist the sector due to insufficient funding. Noteworthy is the Bank of Industry though with an enhanced capital has not impacted significantly on the real sector. Other financing initiatives have not impacted in any noticeable manner, especially Small and Medium Enterprises Equity Investment Scheme (SMEEIS), Agricultural Credit Support Scheme (ACSS) and NERFUND. The SMEEIS fund has been nonplussed due to non-performance and for working at cross purposes, inefficient perfor- mance, while NERFUND has been taken over by the CBN and the NDIC as a result of negative equity and inability to perform. Most of these development finance institutions do not report their financial statements thus making thorough evaluation of activities and operations impossible. A number of innovative finance methods that were introduced such as DIFFRI (Directorate of Food Rural Roads and Infrastructure) in the mideighties, NAPEP and FEAP (Family Economic Adjustment Programme) much later and others had not been quite successful. The Overseas Development Assistance (ODA) and International Finance Corporation (IFC) which are the foreign counterparts of the innovative finance strategies have fared better because of private sector involvement and management. Ajayi, Azim and Ullah (2014) theorise that the innovative process into financing strategies have failed in Nigeria as a result of corruption and other social vices that are constantly anti-development. The mode that adopts the private sector management has been more productive than those channelled through the public financial system.

With the recapitalisation, mergers and acquisitions exercises of 2004/2005 in the banking sector, it was believed that the new status of the banks would stimulate improved funding for the real sector. That only happened in the space of two years when banks lent big ticket loans and syndicated sizeable amounts of credit. But these hopes have been dashed in a whirlwind of short term speculation engaged by the banks through margin funding of the boom in the capital market prior to the global financial crises (GFC) to which substantial amount of capital was lost. Juxtaposed with this is the nature of the banks in Nigeria that lends very short, which is highly unsuitable for real investment. The aftermath of the crises has made the banks to be more cautions, discouraging real investment in the three key sectors while commercial and consumer finance have been heavily favoured. 


\section{The Challenges of the Nigerian Business Environment}

The economy of any country is as desired by its leaders, intelligentsias and the elites (political and economic) of the country and not a one sector show just like the financial system is a development to the micro elements in that economy. Businesses are spawned up, nurtured, survive and mature by a myriad of factors that is domestically present within the economy. The impact of infrastructure on growth is positive (Bende-Nabende \& Ford, 1998). Since Akinbogun (2008), few studies have been done on this all-important topic, though investors through daily newspapers complain loudly all the time. Edun, Akinde, Olaleye and Idowu (2013) asserts that public infrastructure enable increase in employment through private investment which is lacking in Nigeria thus leading to unemployment and increased poverty.

The business environment is daunting to any breed of investment and especially to local entrepreneurs investing in sectors that require little import content input. Other major difficulties in particular are in the areas of infrastructure with power being the most critical. Total megawatt of electricity has remained the same over the last 35 years of Nigeria's existence (at somewhere less than 4,000 megawatts), whereas demand has grown astronomically with rising income. Other infrastructure frequently cited as critical but which the domestic entrepreneurs have had to invest and provide on micro basis for own industrial consumption are water, logistics and transport facilities that are regularly taken for granted in industrialised economies. For domestic entrepreneurs, these have pushed up investors cost profile and elongated payback periods. Other recent but important challenges facing Nigeria are security issues (armed attacks, insurgency and ethnic militias: for example Boko Haram and MEND), inconsistent government policies and lack of government support. Business challenges that have withstood entrepreneurs in Nigeria from businessmen point of view are grouped into social and political. Ranking in the order of importance, energy and power comes first again; other social problems are rising like crime wave, insecurity, education and health sectors having suffered from years of neglect and absence of social insurance. The Central Intelligence Agency reports that in spite of the exploitation of natural resources (crude petroleum) over several decades, Nigeria is still grappling with the inadequate power supply, serious infrastructural deficit, lethargy in passing of legislative reforms to improve governance standards, inefficient property registration process, restrictive trade policies and inconsistent regulatory environments. Slow and ineffective judicial process, unreliable adjudication process, insecurity and lately insurgency and most importantly corruption pervade the entire country. A perfect example is the cost of doing business in Nigeria, which is reputed to be one of the most expensive in sub-Saharan Africa apart from Kenya (World Bank, 2014). These have the effect of driving serious entrepreneurs and innovators out the economy (Ndege, 2012; Cheri \& Ibrahim 2013).

On the political landscape, the risk to the existence and the cohesion of the country as elections approach are significant with regional and ethnic tensions assuming greater dimensions. Political corruption across all the levels of public service assumes high inexcusable levels, while multiple taxes from the local and state governments that are hardly reported drain up small and start-ups micro and small enterprises resources. The government seeming acquiescence to the status quo is worrisome and seems to complete the rounds of corruption that is going on.

Economically, the challenges to business thriving in Nigeria are in the areas of high exchange rates in an economy that is mostly import dependent even for processing firms with concerns for possible devaluation when the parallel premium goes higher than 5\%. High interest rates, shallow financial markets and inconsistent economic policies especially on local content (for instance, 
the Petroleum Industry Bill and new policy on car manufacturing) which make the government either not to be taken seriously or be distrusted, permeate the environment. Having been in military governance for so long, the benefits of the democratic process is yet to be fully achieved as firms have not fully risen to use the democratic springboard to develop. Theorists (Appadorai, 1977, in particular) have established that competition for power should not be aimless but purposeful for economic empowerment, though Akwara, Akwara and Udaw (2014) have advocated the mixing of politics with business and that business returns look up brighter during political transitions. However, a dividing line must be established to keep business firms insulated from political horse trading. Successful businessmen have not been known to be great politicians.

\section{Risks in the Business and Investment Environments}

From all indications the Nigeria business environments is perhaps one of the most risky for this geographical contraption and entity brings some risks to the fore in business planning. Risks makes business forays expensive and more uncertain. The challenges enumerated above constitute the main risks faced by the Nigeria business. The risks make investment a worthwhile activity in Nigeria guaranteeing investor higher returns than would ordinarily be possible elsewhere. Generally, investors have preferred short term investment with guaranteed liquidity. Finance theory proves that long term investments are more worthwhile, enduring, profitable, and generally development enhancing. The real Nigeria businessman does not have resources to fully fulfil his dreams while the investors are looking for short term returns!

Risks to business ventures in Nigeria have deep rooted political foundations that make business to be uncertain about the future of their investments. The social and economic issues all have politics at the root and could be solved from the political angle if the country's leadership with possess the courage to tackle the challenges headlong. While Nigeria's problems could be said to be many, a recent study narrows it to just two: militancy and deficit infrastructure. The insurgency that that is being witnessed undoubtedly has its roots in politics and not religion. While restive the Movement for the Emancipation of Niger Delta (MEND) youths were receding via an expensive surrender package, Boko Haram was rising in the north, both stifling efforts to make the environments attractive to foreign investors.

Infrastructural deficit of the Nigerian environment is notable and has been in sorry state for a long time, with the quality and efficiency of public sector investment going down all of the time. Investments from the public sector achieve less, and costs and prices of public procurement on the high side. Patunola (2013) exhaustively renders the areas of infrastructural development for Nigeria and the main critical areas ranging from energy and power to land usage and development. Transport infrastructure (all types: air, land and sea) is highly deficient leading to congestion and overuse of the existing road system. The study advocates the following as measures to end the inadequacy of the facilities: formulation of infrastructure and utility sector policy, sustainable private sector investment, Private sector participation (PSP), Infrastructure sector restructuring, market reform and direct Government investment. The reasons local entrepreneurs are unable to invest might include any of the above.

Though Nigeria outperformed the best of subSaharan African country (Botswana) in credit access days, the indices generally portrays the country as lagging behind and uninterested in the allowing business to flourish. In fact this report, World Bank (2014) indicates a worsening situation for the country having dropped nine places from 138 to 147. A perfect example of resolving personal insolvency is the case of Bankruptcy Act of 1979 that has never been subjected to test by anybody being adjudged bankrupt in Nigeria. 
Table 1. Selected points on doing business in Nigeria

\begin{tabular}{|c|l|c|c|c|c|l|}
\hline \multicolumn{1}{|c|}{ Key Measures } & Nigeria & $\begin{array}{c}\text { South } \\
\text { Africa }\end{array}$ & $\begin{array}{c}\text { United } \\
\text { Kingdom }\end{array}$ & $\begin{array}{c}\text { Best in } \\
\text { SSA }\end{array}$ & Best Country \\
\hline 1 & Starting a Business (days) & 122 & 64 & 28 & 96 & 1 New Zealand \\
\hline 2 & Obtaining construction permits & 151 & 26 & 27 & 69 & 1 Hong Kong \\
\hline 3 & Getting electricity (days) & 185 & 150 & 74 & 107 & 1 Iceland \\
\hline 4 & Registering property (days) & 185 & 99 & 68 & 41 & 1 Georgia \\
\hline 5 & Getting Credit (days) & 13 & 13 & 1 & 73 & 1 Malaysia \\
\hline 6 & Protecting Investors & 68 & 10 & 10 & 52 & 1 New Ireland \\
\hline 7 & Paying Taxes & 170 & 24 & 14 & 47 & 1 (UAE) \\
\hline 8 & Trading Across borders & 158 & 24 & 16 & 145 & 1 (Singapore) \\
\hline 9 & Enforcing contracts & 136 & 83 & 56 & 43 & 1 (Luxembourg) \\
\hline 10 & Resolving Insolvency (rank) & 107 & 82 & 7 & 34 & 1 (Japan) \\
\hline
\end{tabular}

Source: Doing Business Index: World Bank (2014)

Processes are rather long and procedures complicated in order to make compromise inevitable. With this, financial corruption has always been the end result.

\section{Returns on Investment in Nigeria}

With the theory of the high returns following high risks, the Nigeria business and investment environment is expectedly one of the most lucrative within the sub-Saharan Africa. With potential GDP growth rate of $11 \%$ and real GDP in excess of $6 \%$ per annum (NBS, 2013) and a growing young population of over 110 million (NPC, 2013), market prospects are profitable and promising. The rate of expansion of the various services sectors is proxied by the increase in employment generated. Education, financial services and the health sectors employment generation in first Quarter of 2013 increased by $50.35 \%, 15.9 \%$ and $15.49 \%$ respectively (NBS Report, 2013) over the previous year. The real sectors has roughly maintained the same manufacturing capacity utilisation rate over the past three years between 2010 and 2012 at $56.44 \%, 55.79 \% 56.38 \%$ respectively (CBN2013). The services sectors have expanded more than the real sectors as a result of multifarious challenges that bedevil manufacturing in the country. Many of the services sector that have expanded have depended on own provision of infrastructure and hard-sought out capital for management to increase output. Also, the return to shareholders on the Nigerian bourse has averaged slightly above $36 \%$ per cent which is higher than what is obtainable in mature and advanced financial markets. Investment in the real sector is said to yield as high as $35 \%$ rather an average of $17 \%$ elsewhere in the world (Ovia, 2014).

\section{Unexploited Business Opportunities}

The indigenisation programme of the 1970s took off the expansion of business opportunities for Nigerians. Duru (2011) mentions three ingredients that influence this more in Nigeria, being the creation of a vision, discovery and leveraging on ones strength while discovering and satisfying the needs of the market. Odia and Odia (2013) believe the entrepreneurship spirit needs to be backed up by hard work and the cultivation of good character and integrity to make a success of business endeavours. The paper rates business attributes and also mentions that skills (86\%) knowledge (96\%) hard-work (98\%) and attitude 
$(100 \%)$ are the cognate requirements for success. From the conclusion of the Structural Adjustment Programme (SAP) in the 1990s, the country has made steady progress in the privatisation of State Owned Enterprises (SOEs) having realised that the commercialisation policy embarked on earlier is little value. Outright sale of government owned enterprises and public sector corporations have largely increased the business and investment opportunities in the Nigerian environment.

Opportunities abound greatly demanding the attention of enterprising investors to seize. Oduoza (2013) relates the business opportunities that have abound in Nigeria in recent time to attract investment from both domestic and foreign investors in linkage from oil and gas (natural resource available) to power (energy provision: much needed) the agricultural sector (waning but can be developed) that provides raw materials for the manufacturing (very much needed) sector while infrastructure (in every form) provides for efficiency in production. The presentation lists the available sectors for investment in no particular order of importance as agriculture, solid minerals, crude oil and natural gas, telecommunication, manufacturing, finance and insurance, wholesale and retail trade, real estate and construction and hospitality and restaurants. In addition to all these, the national investment infrastructure is generous on all fronts offering a range of incentives from long tax holidays (up to ten years), duty waivers and capital allowances and others (NIPC, 2013), to ensure that both domestic foreign investors participate in the economy.

\section{Business Financing and Net Capital Flows}

One major issue about the Nigeria financial system is the lack of depth. Lack of financial deepening causes the outflows of funds of the economy since there are not enough instruments to invest in and insufficient mechanisms through which fund can be made available to borrowers. Nzotta and
Okereke (2009) found especially that the main enablers of financial intermediation were simply insignificant in their analysis of Nigeria. Alongside this, incomes have increased and the middle class is coming up once again. Now, the Nigeria elites have developed unbridled taste for consuming foreign goods and services. This is manifested the gross barter terms of trade that have continually increased over the last 10 years. Furthermore, net capital flows have been noticed to be against Nigeria since more than 10 years ago. UNCTAD (2000) authoritatively shows the net increase of outflows out of Africa increased through the years from 9 cents to 34 cents through the years of 1975 to 1999 . The data show the exceptional case of Nigeria being the most affected of the sub-Saharan Africa. These flows had negative implication on the external reserves of the country. The document notes that residents had begun to invest abroad. This has now graduated to a craze by the elite in Nigeria. Recent study (Adaramola \& Obalade, 2013) discovers that capital flight has only short run disturbances on the financial system but recommends creation of business environments that is conducive for business growth. In addition the IIF (2013) itemises the serious effect of the domestic resident investment in overseas countries as well as debt payment services as major causes of negative net flow for most emerging African countries, Nigeria in particular.

\section{Nigeria and Foreign Investment Flows}

The flows out of emerging market economies, Nigeria inclusive is made of domestic capital and profit raking from the hot flows induced portfolio investment. The features of these flows are important because they describe the short and long term expectations of the total capital stock the country holds. With portfolio higher than direct investment in Nigeria, the outlook for a positive aggregate net flow is not in view. Portfolio investment has been consistently higher than direct since the global 
financial crises of 2007-2010. This implies that the hedge funds and other portfolio investors from mature financial markets would continually invest in the frontier and emerging financial markets for profit. This is in spite of the political and country risks facing most of these countries (Institute of International Finance, 2014). A plethora of reasons could be adduced to the problem of net outflows of capital from developing to developed countries cannot be fully explained here given the nature and the reasons for these unusual flows. Prasad (2008) documents these noticeable flows from the emerging economies as mainly being from the reserves accumulation and other salutary macroeconomic reasons. It is quite clear that a closer look and study would reveal deeper problems than are exposed in that paper.

The interest of fund managers in the emerging and frontier financial markets which is observed to be more volatile than emerging markets rose in the first half of 2014, with various Public Offer listings simultaneously carried in Nigeria, South Africa, Tunisia and Morocco. The total values of these offerings rose beyond the previous years of 2012 and 2013. Stock market activities heightened implying that dull markets have become more active especially with the new listings (WSJ, 2014). The Fund managers are very active especially in capital markets taking positions and benchmarking against the Morgan Stanley Capital International (MSCI) 100 index. This index includes some publicly listed firms (especially of the major banks) in Nigeria. Nigeria's weight (about 14\%) in the index is second to Kuwait (also 14\%). These exert pull pressure on the market capitalisation on the Nigerian Stock Exchange with the understanding of the fact that the financial services sector of the Exchange is the most active and perhaps the most liquid. The return from this sector is arguably sufficiently high to enjoy sustained investors' interest.

The effect of the FDI on the economy is salutary especially on the real sector employment prospects. This is encouraged more frequently than the portfolio variety. One main damaging impact of portfolio investment in Nigeria is the effect on the exchange rate as suspected by policy makers in the country. Central Bank of Nigeria (2012) decried the preponderance of portfolio over direct investments when the balance of portfolio reached over $62 \%$ of total capital inflows. In addition, Nwosa and Amassoma (2014), adopting an error correction model conclude that the impact of the portfolio investment was rather negative on the exchange rate whereas the FDI was slightly positive. However, the positive effect of portfolio investment on the capital market activities and capitalisation cannot be ignored (Eniekezimene, 2013). The paper reports that the speed of adjustment from the short to long run is about $66 \%$. Most studies done on the impact of FPI in the financial system and economy are neither conclusive about the results nor exact about implications: most time not alluding to the actual results that have been observed including the implications of such results on the larger economy or the financial system. Since the liberalisation of capital account of the Balance of Payments in 2006, foreign entities bringing in capital only need to obtain a Certificate of Capital Importation into Nigeria to enable eventual transfer such funds with the returns at the expiration of their investment horizon. By this liberalisation, Nigerians are also allowed to invest in foreign currency securities subject to repatriation of the earnings from the investments into domiciliary accounts (Englama, Duke, Ogunleye \& Ismail, 2010).

\section{METHODOLOGY}

Thus to analyse the proposition properly the study focuses on investment and external reserve of the country as the main independent variables. Some propositions are tested here to prove the argument 
about the investment situation and the crises of confidence faced by various entrepreneurs. The chapter proposes hypotheses are as follows:

$\boldsymbol{H}_{\boldsymbol{0}}$ : That investment in the Nigerian economy is not significantly affected by the financial crises.

$\boldsymbol{H}_{\boldsymbol{0}}$ : That the impact of financial crises is not significant on the external reserves of the country.

To test the hypotheses the paper adopts some variables that are important to the financial system during the crises. The data used however extend beyond the period to make room for testability and mainly for lack of adequate data. The paper adopts the multiple ordinary least regression and graduates the process into a two stage least squares (2sls) regression to test one of the hypothesis (1) stated above. Generally, the OLS is of the following form:

$Y=a+b_{1} * X_{1}+b_{2} * X_{2}+\ldots+b_{p} * X_{p}$

where $Y$ is the dependent variable and $a$ as constant and $b_{I} X_{1}$ up to $b_{p} X_{p}$ are the various dependent variables.

To measure the integrated nature of investment in the equation, the study adopts a two stage least square process to measure a key dependent variable in the chapter. The 2 sls process begins with:

$y_{1}=\beta_{0}+\beta_{1} y_{2}+\beta_{2} z_{1}+u_{1}$

and

$y_{2}=\pi_{0}+\pi_{1} z_{1}+\pi_{2} z_{2}+\pi_{3} z_{3}+v$

Thus two major models are used to analyse the hypotheses and obtain results, explicitly the two stage least squares is modelled as follows: The 2sls uses one of the independent variables as the exogenous variable for the second equation. The instrumental variables are explicitly expected to be more in number than the original equation.

$\operatorname{Invt}_{t}=f\left(\operatorname{int} r t\right.$, savgs $\left._{t},\right)$

Savgs $_{t}=f\left(\right.$ extr $_{t}, N p v t_{t 1-t}$, cptil $_{t}$, mktcp $\left._{t}\right)$

While the single equations are modelled explicitly as follows:

Estr $_{t}=f\left(n p v t_{t 1-t}\right.$ mktcp $_{t}$, cptil $_{t}$ savgs $_{t}$ Invt $\left._{t}\right)$

$N P v t_{t 1-t}=f\left(m k t c p\right.$, int $r$, extr $\left._{t}\right)$

where Invt, intr, savgs, Savgs, extr, Npvt ${ }_{\text {t1-t, }}$ cptil, mktcp are the variables of interest in the study and represent domestic investment, interest rate, domestic savings external reserve net portfolio investments real sector capacity utilisation and market capitalisation respectively.

The analytical framework expresses the fact the domestic investment is a function of interest and savings as defined in equation (1). Savings as $y$ in equation (1) is defined in equation (2) as being propelled during the crises by external reserves, net portfolio investments, market capitalisation and capacity utilisation. Equation (3) expresses the fact external reserves are a function of net portfolio investment, market capitalisation, interest rate and domestic investments. Finally, net portfolio investment is a function of market capitalisation interest rate as proxy for market return and external reserves (4). 
Business Investment and the Nigerian Investible Capital Haemorrhage

Table 2. Descriptive statistics of the variables

\begin{tabular}{|l|c|c|c|c|c|c|c|c|}
\hline & CPTIL & XCRTE & INTRE & INVT & EXTR & NPVT & MKTCP & SAVGS \\
\hline Mean & 49.2444 & 112.7376 & 22.5566 & 1560.16 & 24.7555 & 550029 & 5465.006 & 23967.49 \\
\hline Median & 54.32 & 127.2424 & 23.27 & 864.5 & 22.65 & 25553.1 & 2506.3 & 13010.97 \\
\hline Maximum & 59.63 & 157.4994 & 24.94 & 4012.9 & 53 & 3411843 & 19077.4 & 80222.13 \\
\hline Minimum & 30.4 & 21.8861 & 18.36 & 204 & 4.1 & -12056 & 262.6 & 3989.45 \\
\hline Std. Dev. & 10.9707 & 45.55968 & 2.32164 & 1414.78 & 17.8553 & 1057155 & 5973.102 & 25142.43 \\
\hline Skewness & -0.72778 & -1.20526 & -0.76789 & 0.63579 & 0.23988 & 1.84736 & 0.865782 & 1.221306 \\
\hline Kurtosis & 1.79932 & 3.174297 & 2.10753 & 1.81721 & 1.43429 & 4.84473 & 2.52845 & 2.981407 \\
\hline Jar-Bera & 2.67022 & 4.380719 & 2.36633 & 2.26195 & 2.01121 & 12.7905 & 2.415507 & 4.475025 \\
\hline Probability & 0.26312 & 0.111877 & 0.30630 & 0.32271 & 0.36582 & 0.00166 & 0.298868 & 0.106724 \\
\hline Sum & 886.4 & 2029.276 & 406.02 & 28082.9 & 445.6 & 9900532 & 98370.1 & 431414.7 \\
\hline S Sq. Dev. & 2046.07 & 35286.63 & 91.6308 & 340272 & 5419.82 & $1.90 \mathrm{E}+1$ & $6.07 \mathrm{E}+08$ & $1.07 \mathrm{E}+10$ \\
\hline
\end{tabular}

Source: Author's Compilation

\section{Data Sources and Definitions of Variables}

The data for the methodology obtained from the Central Bank of Nigeria Statistical Bulletin (2014) are, market capitalisation of the stock exchange, interest rate, exchange rate, capacity utilisation of domestic manufacturing firms, net portfolio investment, net savings, external reserves and investments (gross fixed capital formation). Data accessed from the National Bureau of Statistics (NBS) website (accessed October 4 2014) are Net portfolio investment (shares) gross fixed capital formation.

\section{RESULTS AND DISCUSSIONS}

A description of the variables show and indicate that various of times series data are available especially for investment for which Gross capital fixed formation is proxy are available for longer years, but data availability on the other variables (especially Net portfolio investment) truncates this to 18 years. The concern about the descriptive is the standard deviation which shows the volatility in a way of the data in the series. NPVT has the highest standard deviation followed by $M K T C P$ and SAVGS in that order. The basic interest here is the earlier variables and especially the NPVT. The variability expressed in the Table 2 reverses when sum squared deviation is used to measure variability, $S A V G S$ is lowest while $M K T C P$ is slightly high while $N P V T$ is highest among the three. Expectedly, the lowest of the SSD is INTR. This scenario points to what the other tables and the regression show of the variables. Another cursory look at the output shows that the variable NPVT has the lowest $p$ value of 0.00166 . Table 2 as shown below contains the descriptive statistics of the other variables used in this study.

\section{Regressions Results}

The results of the regressions are more exemplifying as some variables deviate from the a priori expectations. The main dependent variable indicates that none of the variables is negative or that the there is a direct positive impact of such variable on the dependent variable. The two stages least square adopted do not impact negatively against the variable of $S A V G S$ which remain positive. The a priori expectation has been that the $N P V T$ would be negative with NIVT. (It is case of investment 
being investment!) The positively significant variables are NPVT significant beyond 0.01 level and $S A V G S$ as expected also beyond 0.01 levels. At least savings follow the a priori expectation. INTR is positive but insignificant. This is in spite of the fact the Nigerian financial market interest rates being one of the highest in the world with spread of sometimes $22 \%$. Thus believably INTR does not negatively impact against investment but positively related to it. EXTR is near significant which would have indicated that INVT has some positive impact from it with $p$ value at 0.1850 and $t$ of 1.414. MKTCP and CPTIL are equally insignificant but positive with INVT at almost the same level.

The second regression to investigate the impact of the GFC on Nigeria with EXTR as the dependent variable shows that two variables are significant and three are negative. The significant ones are $M K T C P$ and $S A V G S$. While $M K T C P$ is positively significant to EXTR beyond 0.01 levels, SAVGS is negatively significant (this is understandable) at the same level, both almost equal with their $p$ values of 0.0176 and 0.0103 respectively. Of importance is the fact that NPVT is negative in the regression. It insignificance indicates that the outflow may not have been sufficiently serious to impact the financial system. That CPTIL is negative in this regression is unusual, even though insignificant. One would think that higher levels of CPTIL would indicate a higher level of external reserve in the sense that more productivity would reduce the need for foreign exchange and would rather increase foreign reserves.

The third regression was to investigate the impact of the independent variables on the NPVT thereby to suggest the possible relationship that may exist. All the independent variables except $I N V T$ are negatively impactful on NPVT except $S A V G S$. The position of savings is already established in the 2SLS regression. The level of significance is considerable for most of the variables. By this regression, four of the variables are significant indicating that it is an important variable in the study. Like its reciprocal, INVT is significant and positively so, and this at a level beyond 0.01 . Others variables are negative and highly significant. SAVGS, EXTR and CPTIL are all negatively significant at various levels. While EXTR is negatively significant beyond 0.05, SAVG and CPTIL are significant beyond 0.01 levels. The meaning of this particular regression result is that the aforementioned variables all impacted negatively against $N P V T$, which is also to say that there is negative relationship in the regression. EXTR is particularly instructive because much of Nigeria reserves have been lost to capital flight occasioned by the hot flows induced by the portfolio investment in the country. The a priori result of $S A V G$ may be understandable as a result of competing position; the implication of NPVT is clear because of the drain on EXTR. Clearly from the regression the above mentioned variables except INVT all have negative relationship one against the other. Table 3 show the results summary.

\section{NIGERIA FINANCIAL CRISES, INVESTMENT AND GROWTH IMPLICATIONS}

The naira has had a trajectory of losses since it was deregulated in September 1986, but none was a significant as the one experienced between the months of November 2008 to February 2009 , right in the middle of the global financial crises of 2007 and 2010. While studies have ascribed the causes to the subprime mortgages losses in the United States, subsequent events in other countries led to flows of capital retracting leading to losses on liquidation of assets. Specifically, the case of Nigeria led to losses in the banking system that had bankrolled stock market trading activities through margin loans causing some amount of instability in the financial system.

In spite of the business opportunities available in Nigeria and insufficiency of capital to power needed investment in critical sectors, the country 
Table 3. Summary of regression results

\begin{tabular}{|c|c|c|c|}
\hline Variables & Invt & Extr & Npvt \\
\hline \multirow[t]{2}{*}{ Constant } & -579.0408 & 1.342004 & 1068925 \\
\hline & $-(0.523031)$ & $(0.12854)$ & (2.06324) \\
\hline \multirow[t]{2}{*}{ Intr } & 14.71694 & - & - \\
\hline & $(0.198981)$ & - & - \\
\hline \multirow[t]{2}{*}{ Savgs } & 0.02799 & -0.00085 & 76.186 \\
\hline & $(3.80543)^{* * *}$ & $\begin{array}{c}(- \\
3.5098) * * *\end{array}$ & $(7.47346) * * *$ \\
\hline \multirow[t]{2}{*}{ Extr } & 12.43647 & - & - \\
\hline & (1.41413) & - & - \\
\hline \multirow[t]{2}{*}{ Mktcp } & 0.02535 & 0.003005 & -49.6338 \\
\hline & $(0.614665)$ & $(3.1082)^{* * *}$ & $\begin{array}{c}(- \\
4.89986)^{* * *}\end{array}$ \\
\hline \multirow[t]{2}{*}{ Npvt } & 0.000460 & $-3.91 \mathrm{E}-06$ & - \\
\hline & $(6.72131)^{* * *}$ & $(-0.8399)$ & - \\
\hline \multirow[t]{2}{*}{ Captil } & 8.867158 & 0.17473 & -2784.23 \\
\hline & $(0.653991)$ & $(0.6608)$ & $(-2.3588)^{* *}$ \\
\hline \multirow[t]{2}{*}{ Invt } & - & 0.01346 & 2440.182 \\
\hline & - & $(1.58892)$ & $(9.4093) * * *$ \\
\hline $\mathrm{R}^{2}$ & 0.9821013 & 0.882341 & 0.903445 \\
\hline Adj. $R^{2}$ & 0.97223 & 0.833316 & 0.855182 \\
\hline F Stat & 100.595 & 17.9918 & 18.7155 \\
\hline D Watson & 2.18518 & 1.754 & 2.2468 \\
\hline Observations & 18 & 18 & 18 \\
\hline
\end{tabular}

Source: Output Variables compiled by the Author. Coefficients, $t$ values are in parentheses.

$* *$, *** represents 0.05 and 0.01 level respectively

has faced continuous capital leakage and outflow from the economy. However, the sources of longterm capital for domestic investment in developing countries remain essentially domestic in spite of the clamour for foreign direct investment in these economies. Aizeman, Pinto and Radziwill (2007) testing the impact of financial globalisation, go lengths to prove that sources of development capital have been primarily from the domestic financial markets of the developing countries surveyed in their paper. The paper concludes that at least $90 \%$ of domestic capital formation could be attributed to domestic savings which questions so much interest on the energy expended to promote FDI and FPI. The paper concludes that financial globalisation and integration can be important only for the diversification of assets and liabilities of domestic residents in these developing countries.

While foreign investors are taking advantage of the situation to invest in the financial market and make quick returns the domestic entrepreneurs are facing hurdles in terms of difficult business environment. These have raise costs of investment and made production efficient. The confidence to invest domestically is singed as a result of difficult conditions. This is one of the reasons for investors to invest externally causing capital flight out of the economy. Domestic investments in key sectors to increase capital formation and thus power capacity utilisation are basic for countries that intend to experience growth and development. The regressions above do not indicate this is happening though portfolio investment is impactful on the economy only be in the short run.

Globalisation has enabled countries to have a more efficient of allocation of capital. Such is Nigeria's case where capital from hedge and institutional investors move to domestic economy to take advantage of illiquid stock market to earn uncorrelated returns from capital appreciation in financial assets in the domestic economy. The amount of investment from the external context has continued to increase in spite of the risks often associated with the environment. This shows that there is some level of confidence in the economy for foreign investors to bring in capital for investment. The analysis of the study has also shown that portfolio investment has increased dramatically and higher than foreign direct investment. Thus portfolio investment takes advantage of the financial markets. Globalisation is reported to be beneficial to countries that have met minimum thresholds in financial development which is lacking in Nigeria. Any type foreign capital flows, whether they are direct or portfolio cannot 
Figure 1. Variations (gaps in market funding) during 2008 financial crises: July - December 2008 Source: CBN's Foreign Exchange Market Operations (accessed 10/07/2014)

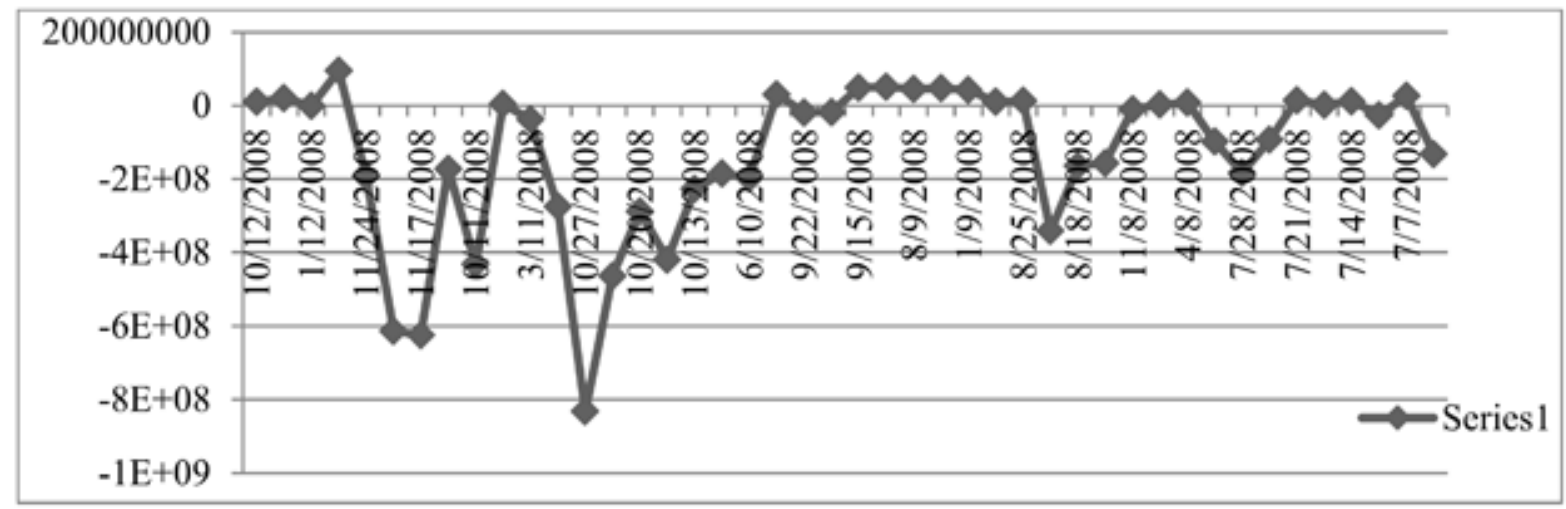

be depended on to aid the development in less developed countries, more of domestic development is possible with domestic capital formation than by anything else.

\section{The Global Financial Crises and International Investment Position of Nigeria}

The financial system was initially believed to be insulated from the crises until a noticeable heavy outflow of foreign exchange was observed by financial analysts. The economy withstood sudden heavy outflows of about $\$ 3,000$ million dollars by hedge and portfolio investors who pulled out their capital as a result of the crises with the banking industry having toxic assets amounting to as much as $\$ 6.9$ billion (about $\$ 973$ billion of which $\$ 400$ billion was directly traceable to the capital market). This short-circuited the progress already made with the recapitalisation programme (Sanusi, 2009).

Precisely from Auction No 82 - 93, the currency behaved very wildly and the insufficiency of supply affected the price to the point that at a particular time between November and December of 2008, the foreign exchange market was shut down as the CBN was unable to meet heightened demand at the managed float price. Figure 2 shows the slight steep increase in the rate of exchange that was reported. In actual fact the currency rates at the spot market at this time is not officially available. The exchange rate (ER) moved to somewhere around $\$ 177.00$ per $\$ 1.00$. The CBN however got its acts together by

Figure 2. Naira exchange rate between June 2008 and 2009

Source: Central Bank of Nigeria website downloads (moving rates per month by author)




Figure 3. Percentage losses of value of the Naira between July 2008 and June 2009 Source: CBN's Statistical Bulletin (2013)



January 2009 allowing a devaluation of $15 \%$ of the currency to stabilise it. Figure 3 shows the percentage increase in ER within the months of November 2008 to March 2010.

The GFC led to Nigeria Naira being suddenly overvalued (in disequilibrium of demand and supply) as a result of continues outflow of foreign exchange out of the economy. At this time foreign portfolio investment were being liquidated from the capital market and subsequently transferred. The spate of dollar purchase forced the demand higher up than available supply of currency and subsequently the rate of the currency went up.

Foreign Portfolio Investment (FPI) no doubt flows into the economy as a result of the confidence that foreign investors have in the country and inflow of FPI is an indication of an open capital account. Punch (2014), indicates the return on the NSE averaged $36 \%$ in the last two years of 2012 (35\%) and 2013 (42\%) and is among the best performing of the African frontier markets. For this reason portfolio investment has been on the increase before this time and at an alarming rate. As it happened in the last GFC when portfolio investors withdrew their capital from the market, one should expect a like withdrawal from the market with the general elections coming up February 2015. It is normal for investors withdraw their funds and minimise losses due to the uncertainty that may result from political risks (the elections). Also, the effect of sudden reversal of flows that can be created by the withdrawal of investments and its repatriation can be dangerous for the type of shallow economy that the Nigerian financial system is.

A mature and advanced financial market that is well deepened may be able to withstand the onslaught of sudden infusion, injection and subsequent withdrawal of foreign capital, but this is not certainly suitable for an economy that needs resources for long-term growth and development, and a deepened real sector to support economic performance. At different times foreign or domestic investors alternately lead in investment in the stock market depending on who has invested more. Figure 4 shows the increasing percentage of the portfolio investment of total foreign investments in the economy; this means it is already higher and has overtaken FDI.

This invidious position has not augured well as the country lost more of its reserves that was built up some years in the past as one of the bastions of the emerging economy status of the country. The International Investment Position (IIP) of the country is therefore in the negative. The Net International Investment Position of the country has been in the negative for longer than it has been positive and has never at any time been higher than $14,772.0$ million where as it has reached 30,179.4 million in the negative. Arguments of the quantum of the NIIP against the GDP may be important if it can be accepted that a now seem- 
Figure 4. Percentages of foreign portfolio flows of total inflows into the financial system Source: Central Bank of Nigeria Annual Report 2011

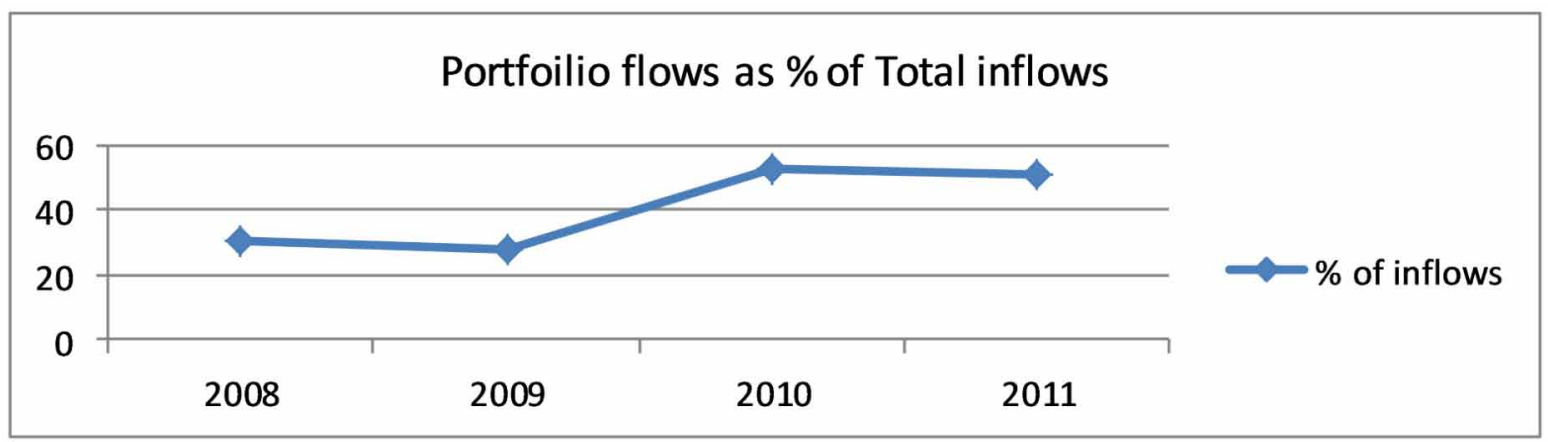

ingly insignificant amount becomes monstrous in the very near future, even in the face of a rebased GDP of $\$ 520$ billion as of 2014 !

The situation above is not certainty induced all by foreign investors who have become regular investors that take positions to maximise their investment in the Nigerian financial system given the risks that are inherent in the Nigerian state and economy, but much more by a plethora of factors emanating from the Nigeria people and State. With the return of democratic governance in 1999, the economic prospects had begun to look up and the middle class returned in a measure with income to consume. Banks began to offer consumer loans targeted at the middle class in the society whose main qualification was regular income above a threshold. Domestic consumption of foreign services increased astronomically that it became a status symbol. In this area, education and health services abroad became affordable as the availability of resources though many of such were procured on credit. Sometimes the credit takes up to four years to repay. Great Britain, Canada and United States are the main beneficiaries of the search for higher education overseas while Germany, India and the United States (in that order) are the major recipients of the benefits of the medical trips out of Nigeria. These and many others are directly paid for through the CBN. Figure 6 shows the relationships between

Figure 5. The net international investment position of Nigeria (2005 - 2013)

Source: Central Bank of Nigeria's Statistical Bulletin 2013

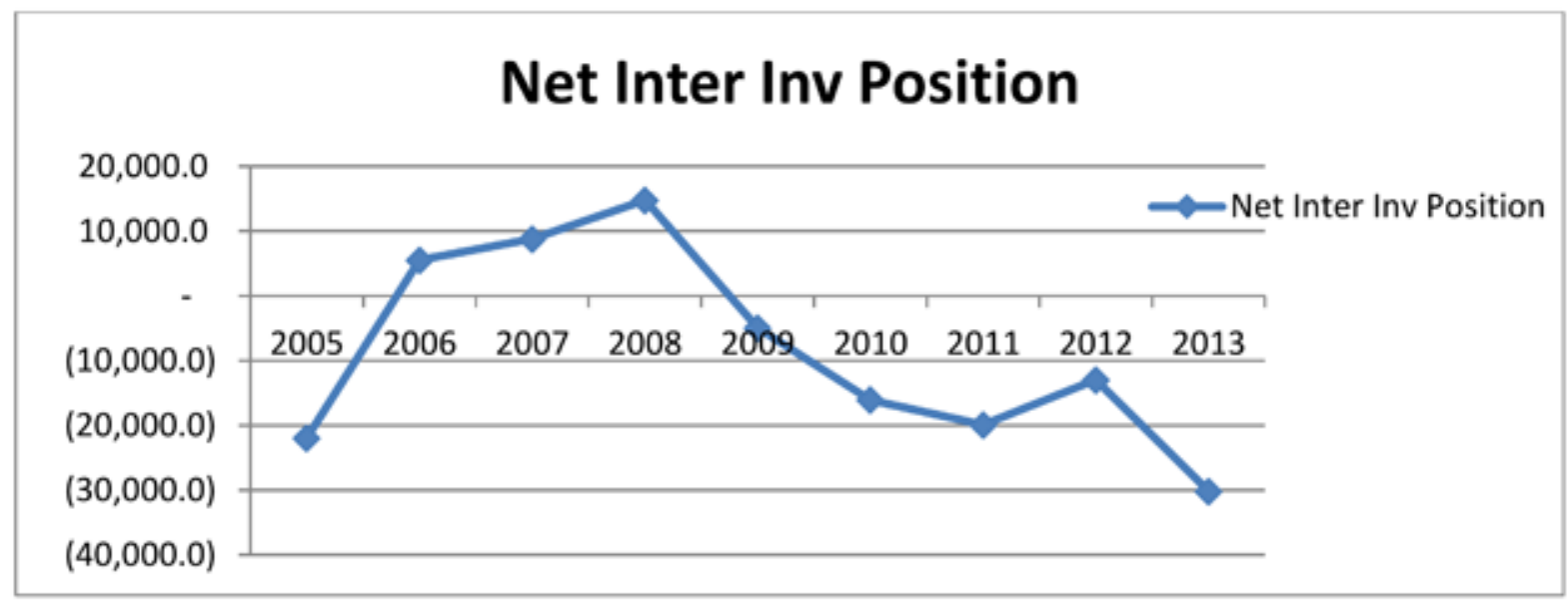


Figure 6. Routes and composition of the outflows from the Nigeria foreign exchange market Source: Central Bank Website on Foreign Exchange markets Operations accessed 16/07/2014

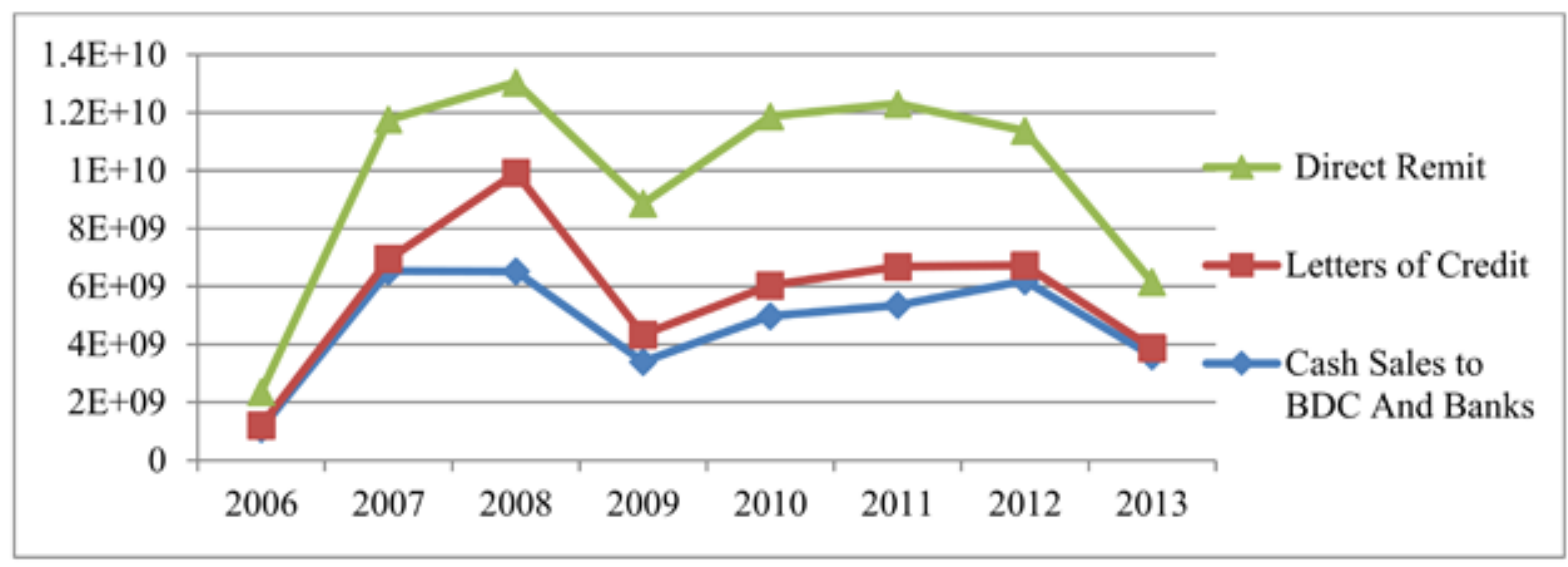

the main routes of foreign exchange leakage of the country. The direct remittances out of Nigeria present the largest routes of the foreign exchange out of Nigeria. The others are Letters of Credit (L/C) and Cash sale to the banks and bureaux de change. The cash sales conducted in the economy has made Nigeria to be the largest importer of the dollar banknote, which according to the erstwhile governor is not good. The importance of this is that the CBN knows all these and can, if it is interested in doing something about it.

Much as the foreign exchange market controlled by the $\mathrm{CBN}$ is the main route of all legal transfers of currency out of the country, other participants in the foreign exchange market were beneficiaries of the currency crises. The obvious point here is that central bank all over the world attempt to control the flow of capital out of the economy in times of currency or financial crises. The CBN continued to allow the flows out the economy without being checked. The main culprit of the flow is portfolio which led to the loss in stock market capitalisation. Strong arguments have been built for control in the inflow of portfolio capital by emerging countries while frontier market could also do the same to safeguard the economy from avoidable leakages and losses of hard earned foreign exchange.

\section{Central Bank and Capital Leakage Control}

Obiechina (2010) intones the intransigent nature of the Central bank in controlling the negative capital flows that has become worrisome because of the nature of the external sector, though the policy makers knows the disruptive nature of the flows. The 2007 GFC caused a spiraling effect in Nigeria leading to about $67 \%$ loss of the market capitalisation. The confidence in the market was at its lowest level and investors' losses (in some cases) were transferred to the banks that held equity investments as collateral. The instant effect of the quantitative easing that Ben Bernanke introduced made the Nigerian $t$ Bills to yield close to $13 \%$, a disservice to short term borrowers in the economy (Farzad, 2012). The immediate monetary challenge of sudden infusion of money to the economy is as dangerous as its effusion.

The failure of the ER as the main control of the $\mathrm{CBN}$ to maintain internal and external balance is clearly seen in the reaction of a very fragile but fledgling financial system that depends largely on the export of crude petroleum to finance its foreign exchange needs. Evans (2002) advocate transparency, good corporate and national governance, rule of law and enforcement of contracts 
as rules to improve the scenarios of portfolio flows. The impossible trilemma ensures that financial system that are serious at achieving good governance for their economies must begin at home by implementing good policies, especially macro prudential policies to improve the banking landscape within the total financial system which definitely impacts on the economy and the external sector. Of the three 'impossibles', monetary authorities attempt to handle the ones they have control over. Capital controls have been revived in some countries when the effusion of foreign reserves was disruptive to their economies: (What the Nigerian CBN has permitted and continues to permit is the transfer of net savings and domestic resources out of the economy.)

\section{RECOMMENDATIONS}

The International Monetary Fund (IMF) has always encouraged the monetary authorities of each country to develop adequate internal capacity to manage sudden flows. Each of these flows is capable to cause financial crises when they happen in concerted manner. Central banks should also sequence properly the capital account opening process to ensure the insulation of the domestic economy in case net flows are not favourable. The Nigerian central bank has already opened the capital account: all it needs to do at this time is to firm up the control to allow inflows and subject them to a minimum residency period before being transferred. There are many choices of these controls.

Central banks of frontier economies must be more proactive in the management of inflows into their economies and their financial system to forestall hurtful capital flow reversals. This is important as the economies may face sudden appreciation and depreciation of their nominal exchange rates which can be impactful against an economy that is import dependent like Nigeria. In addition, the use of controls does not render the country any less important in the current financial globalisation process across financial market in the world.

The immediate benefit of the domestic market has always been the market-making process where equity, stocks and bond markets to react to changes in the perception of investors. There can be a better way to ingenuously bring this about. The fundamentals of the affected stocks are enough incentive to induce a re-pricing of such stocks if there is enough liquidity in the financial system. Available liquidity enables investors to make market given the sufficient knowledge of the market. The main benefit of an open capital account has always been what is accruable in the international allocation of capital for more efficient uses.

The encouragement of mutual funds and other collective investments is very important in encouraging the capital market to grow. Hedge and other like funds have ancillary function they perform in the process of investment that make them important in the strengthening of the capital market. Such functions as research and investigation of companies for the purposes of investment become easily available. Central banks should rather look to this option rather than allow portfolio investors to transfer net saving out of the economy.

Central banks should as a matter of national development objective create pools of funds that can be used to aid the development of key sectors in their various economies. This though not a direct function of central banks, but would help the economy to achieve real growth that in the long run steady the economy when there are crises such as the last global financial crises. This happily the CBN is currently pursuing. Much of the developmental objectives of the country are now being financially incentivised by the Central bank of Nigeria. Such Funds for infrastructure, agriculture and the like have been established to assist the development of structures for the different sectors of the economy. 


\section{CONCLUSION}

Business investments require capital which is not readily available in the financial system due to a plethora of problems. The development finance institutions established to assist this regard have largely failed to fulfil their objectives. In the face of serious business opportunities that are available and high returns possible within the economy, serious capital outflows are happening due to the global financial crises and the nature of the Nigerian domestic economy which encourages consumption of imported goods and services as a result of increasing member of the medium class and primarily because the economy encourages portfolio flows which is hot in nature. Capital outflows can be dangerous for the economy if is sustained over a period of time and is uncontrolled. It is also suggested that measures be taken to strengthen the financial system to with stand the possible reversal of capital flows in the future through macro prudential guidelines for the financial system. The central bank is expected to proactively manage the external sector rather adopt a carefree attitude. This would assist in the reduction in capital outflows from the economy and in turn allow more capital to be available within the financial system to assist entrepreneurs who need such capital for investment purposes

\section{REFERENCES}

Adaramola, A. O., \& Obalade, A. A. (2013). Does capital flight have a force to bear on Nigerian economic growth? International Journal of Developing Societies, 2(2), 80-86. doi:10.11634/216817831302422

Adegbite, O. E., \& Adetiloye, K. A. (2013). Financial globalisation and domestic investment in developing countries: Evidence from Nigeria. Mediterranean Journal of Social Sciences, 4(6), 213-223. doi:10.5901/mjss.2013.v4n6p213
Adetiloye, K. A. (2011). Capital flight and financial globalisation: Will further opening up increase capital flight out of Nigeria? International Business Management, 5(6), 349-356. doi:10.3923/ ibm.2011.349.356

Adetiloye, K. A. (2012). Capital flight versus domestic investment in developing countries: An empirical analysis from Nigeria International. Journal of Economics and Finance, 4(2), 175-186. doi:10.5539/ijef.v4n2p

Aizenman, J., Brian, P., \& Radziwill, A. (2007). Sources for financing domestic capital: Is foreign saving a viable option for developing countries? Journal of International Money and Finance, 26(5), 682-702.

Aizenman, J., \& Pasricha, G. K. (2013). Why do emerging markets liberalize capital outflow controls? Fiscal versus net capital flow concerns. Journal of International Money and Finance, 39(C), 28-64. doi:10.1016/j.jimonfin.2013.06.018

Ajayi, O. D., Azim, M. S., \& Ullah, M. S. (2014). The imperatives of innovative sources of development finance: Evidence from Nigeria Research. Journal of Finance and Accounting, 5(14), 62-66.

Ajayi, S. I. (1992). An economic analysis of capital flight from Nigeria. World Bank Policy Research Working Paper No. 993.

Akinbogun, T. L. (2008). The impact of Nigerian business environment on the survival of smallscale ceramic industries case study, south-western Nigeria. Journal of Asian and African Studies, 43(6),663-679. doi:10.1177/0021909608096659

Akwara, A. F., Akwara, N. F., \& Udaw, J. O. F. (2014). Business and its environments: Business opportunities open to small-scale enterprises during political transition periods in sub-Sahara Africa. Journal of Good Governance and Sustainable Development in Africa, 2(1), 14-25. 
Alfaro, L., Kalemli-Ozcan, S., \& Vadym, V. (2008). Why doesn't capital flow from rich to poor countries? an empirical investigation. The Review of Economics and Statistics, 90(2), 347-368. doi:10.1162/rest.90.2.347

Appadorai, A. (1977). Substance of Politics. Madras: Oxford University Press.

Bekaert, G., Harvey, C. R., \& Lundblad, C. (2005). Does financial liberalization spur growth? Journal of Financial Economics, 77(1), 3-55. doi:10.1016/j.jfineco.2004.05.007

Bende-Nabende, A., \& Ford, J. L. (1998). FDI, policy adjustments and endogenous growth: Multiplier effects from a small dynamic model for Taiwan, 1959-1995. World Development, 26(7), 1315-1330. doi:10.1016/S0305750X(98)00043-6

Calvo, G., \& Reinhart, C. (2000). When capital inflows come to a sudden stop consequences and policy option. In P. Kenen \& A. Swoboda (Eds.), Reforming the International Monetary and Financial System (pp. 175-201). Washington, DC: International Monetary Fund.

Central Bank of Nigeria. (2010). The changing structure of the Nigeria economy. Abuja: Central Bank of Nigeria.

Central Bank of Nigeria. (2013). Statistical Bulletin. Abuja: Central Bank of Nigeria.

Central Bank of Nigeria. (2013). Average manufacturing capacity utilization. Retrieved from http://statistics.cbn.gov.ng/cbn-onlinestats/QueryResultWizard.aspx

Central Intelligence Agency. (2014). Nigeria: economy. Retrieved from https://www.cia.gov/ library/publications/the-world-factbook/geos/ ni.html

Collier, P., Hoeffler, A., \& Pattillo, C. (2004). Africa's Exodus: Capital flight and the brain drain as portfolio decisions. Journal of African Economies, 13(2), 15-54.
Collier, P., Hoefler, A., \& Pattilo, C. (2001). Flight capital as a portfolio choice. The World Bank Economic Review, 15(1), 55-80. doi:10.1093/ wber/15.1.55

Duru, M. (2011). Entrepreneurship opportunities and challenges in Nigeria. Business and Management Review, 1(1), 41-48.

Edun, A. O., Akinde, J. O., Olaleye, S. O., \& Idowu, G. A. (2013). Infrastructural development and its effect on economic growth: The Nigerian perspective. European Scientific Journal, 9(31), 431-452.

Eiekezimene, A. F. (2013). The impact of foreign portfolio investment on capital market growth: Evidence from Nigeria. Global Business and Economics Research Journal, 2(8), 13-30.

Englama, A., Duke, O. O., Ogunleye, T. S., \& Isma'il, F. U. (2010). Oil prices and exchange rate volatility in Nigeria: An empirical investigation; Economic and Financial Review. Central Bank of India, 48(3), 31-48.

Evans, K. (2002). Foreign portfolio and direct investment complementarily, differences, and integration. Paper presented at the Global Forum on International Investment Attracting Foreign Direct Investment for Development Shanghai, 5-6 December.

Farzad, R. (2012). Ben Bernanke's gift to Africa. Bloomberg Business Week Market and Finance, November 1

Ifeakachukwu, N. P., \& Ditimi, A. (2014). Capital inflows and exchange rate in Nigeria Mediterranean. Journal of Social Sciences, 5(7), 263.

Institute of International Finance. (2014). Capital flows user guide. Institute of International Finance Research Note.

Institute of International Finance. (2014). Capital flows to emerging market economies. Institute of International Finance Research Note, January. 
Khose, M. A., Prasad, E. S., \& Terrones, M. E. (2003). Financial integration and macroeconomic volatility. IMF Staff Papers, 50, 119-142.

Kindleberger, C. P. (1987). Capital Flight: A historical perspective. In Lessard and Williamson (Eds.), Capital flight and third world debt. Washington DC: Institute for International Economics.

Lane, P. R., \& Milesi-Ferretti, G.-M. (2010). The cross-country incidence of the global crisis. Paper prepared for the IMF/BOP/PSE conference economic linkages, spillovers and the financial crisis. Paris, January. doi:10.1057/imfer.2010.12

Lawan, C. \& Ahmadu, I. (2013). An assessment of the challenges and prospects of power sector reform in Nigeria from 2000-2013. Review of Arts and Humanities, 2(2).

Lucas, R. (1990). Why doesn't capital flow from rich to poor countries? The American Economic Review, 80(2), 92-96.

McGrath, J. (2014). African ipo fund-raising surpasses 2013 in first half of 2014. The Wall Street Journal: Market and Finance $23^{\text {rd }}$ July Accessed on $26 / 07 / 2014$

Moreno, R. (2011). Lessons on the "impossible trinity Notes on introductory remarks prepared for the BIS-sponsored high-levelpanel responding to capital flows: what have we learned? At the LACEA meeting in Santiago, Chile in November.

National Bureau of Statistics (2013). 4th Quarter 2012 \& 1st Quarter 2013 Job creation survey. National Bureau of Statistics, The Office of the Chief Economic Adviser to the President, Federal Ministry of Labour \& Productivity, and National Directorate.

National Population Commission and ICF International.(2014). Nigeria demographic and health survey 2013 Rockville. Maryland, USA: National Population Commission and ICF International.
Ndege, Y. (2012). Explaining Nigeria's energy crises. Retrieved from http://blogs.aljazeera.com

Ndukumana, L., \& Boyce, J. K. (2003). Public debts and private assets; explaining capitalflight from Sub-Saharan African Countries. PERI Working Paper, 32

Nzotta, S. M., \& Okereke, E. J. (2009). Financial Deepening and economic development of Nigeria: An empirical investigation African Journal of Accounting, Economics. Finance and Banking Research, 5(5), 52-66.

Obiechina, M. E. (2010). Capital flows and financial crises: Policy issues and challenges for Nigeria. Central Bank of Nigeria Economic and Financial Review, 48(1), 93-112.

Odia, J. O., \& Odia, A. A. (2013). Developing entrepreneurial skills and transforming challenges into opportunities in Nigeria. Journal of Educational and Social Research, 3(3), 289-298.

Oduoza, P. (2013). Doing business in Nigeria: creating wealth fromopportunities in Africa'slargest market. from http://allafrica.com/download/ resource/main/main/idatcsaccessed15/07/2014

Olayinka, M., \& Adebisi, J. F. (2013). Small business financing in Nigeria: An investigation of the angel option. Canadian Social Science, 9(2), 9398. doi:10.3968/j.css.1923669720130902.7193

Ovia, J.(2008). Blossoming the Nigerianeconomy: Real sector financing. Central Bank of Nigeria's National Seminar on Banks \& the Nigerian Economy. Sheraton Hotel \& Towers, Abuja. Tuesday February 12(2).

Ovia, J. (2014). World economic forum: wooing investors to Nigeria. The Nigerian observer. 25 th February.

Patunola, B. A. (2013). Infrastructure development and economic empowerment in Nigeria. The Nigerian Institution of Estate Surveyors and Valuers. 
Prasad E. (2008). Financial globalization: What to think when capital flows uphill. The Milken Institute Review, Second Quarter 2008.

Punch Newspapers. (2014). NSE's return drops by $30.4 \%$ in seven months. Reported 30 July 2014.

Sanusi, L. S. (2009). Developments in the Nigeria banking system. Being the address by the central bank of Nigeria's Governor on five insolvent banks on $14^{\text {th }}$ August.

Uche, C. C. N., \& Onwuka, K. O. (2012). Do domestic conditions matter for investments? evidence from Nigeria Data. Universal Journal of Management and Social Sciences, 2(11), 1-15.

United Nations Conference on Trade and Development. (2000) Capital flows and growth in Africa . Geneva, United Nations.

World Bank. (2013). Doing business 2014: understanding regulations for small and medium-size enterprises. Washington, DC: World Bank Group. doi:10.1596/978-0-8213-9615-5

\section{KEY TERMS AND DEFINITIONS}

Business Environments: The total infrastructure of the country to support the establishment and growth of business firms. The soft and real capital to enable business firms to be more productive, for instance energy and institutions.

Capital Outflows: The outflows and inflow of financial resources in a country. This often caused by investment activities of both residents and non-residents. It often has serious implications for the country's ability to invest domestically.

Emerging Markets: These are countries that have recently deregulated their financial markets and are receptive to private enterprise.

Exchange Rates: The price of one currency in terms of another. It is often impacted by the capital flows.

External Reserves: The total stock of financial assets that a country has often denominated in foreign currency, and other liquid foreign financial assets. It represents the means by which the country can make international settlement.

Portfolio Investments: The type of financial investment from foreign countries in a country that are invested in stocks and shares bonds. It is often short term in nature. 